\title{
Cerebellar Directed Optogenetic Intervention Inhibits Spontaneous Hippocampal Seizures in a Mouse Model of Temporal Lobe Epilepsy ${ }^{1,2}$
}

\author{
DEsther Krook-Magnuson, Gergely G. Szabo, Daren Armstrong, Mikko Oijala, and Ivan Soltesz
}

DOI:http://dx.doi.org/10.1523/ENEURO.0005-14.2014

Department of Anatomy and Neurobiology, University of California, Irvine, Irvine, California 92697

\begin{abstract}
Temporal lobe epilepsy is often medically refractory and new targets for intervention are needed. We used a mouse model of temporal lobe epilepsy, on-line seizure detection, and responsive optogenetic intervention to investigate the potential for cerebellar control of spontaneous temporal lobe seizures. Cerebellar targeted intervention inhibited spontaneous temporal lobe seizures during the chronic phase of the disorder. We further report that the direction of modulation as well as the location of intervention within the cerebellum can affect the outcome of intervention. Specifically, on-demand optogenetic excitation or inhibition of parvalbumin-expressing neurons, including Purkinje cells, in the lateral or midline cerebellum results in a decrease in seizure duration. In contrast, a consistent reduction in spontaneous seizure frequency occurs uniquely with on-demand optogenetic excitation of the midline cerebellum, and was not seen with intervention directly targeting the hippocampal formation. These findings demonstrate that the cerebellum is a powerful modulator of temporal lobe epilepsy, and that intervention targeting the cerebellum as a potential therapy for epilepsy should be revisited.
\end{abstract}

Key words: cerebellum; epilepsy; hippocampus; optogenetics; Purkinje; seizure

\section{Significance Statement}

Epilepsy is a condition of spontaneous recurrent seizures. Current treatment options for epilepsy can have major negative side effects and for many patients fail to control seizures. We detected seizures on-line and tested a new selective intervention using a mouse model of temporal lobe epilepsy. In this form of epilepsy, seizures typically arise in the hippocampus. We report that targeting intervention to a distinct brain region, the cerebellum, significantly inhibits hippocampal seizures. This identifies the cerebellum as a potential future therapeutic target for temporal lobe epilepsy.

${ }^{1}$ Author contributions: E.K.-M., G.G.S., C.A., and I.S. designed research; E.K.-M., G.G.S., and C.A. performed research; M.O. contributed unpublished reagents/analytic tools; E.K.-M. and G.G.S. analyzed data; E.K.-M., G.G.S., C.A., and I.S. wrote the paper.

${ }^{2}$ The authors declare no competing financial interests.

This work was supported by NIH Grant K99NS087110 (to E.K.-M.), the Epilepsy Foundation (to C.A.), the George E. Hewitt Foundation for Medical Research (to G.G.S.), the University of California Irvine Center for Autism Research and Treatment (to I.S.), and NIH Grant NS074432 (to I.S.). We thank Cecilia Lozoya, Judit Vargane, Rose Zhu, Chris Krook-Magnuson, Sean Lew, and Dhrumil Vyas for technical support.

Correspondence should be addressed to Esther Krook-Magnuson, Department of Anatomy and Neurobiology, University of California, Irvine, 192 Irvine Hall, Irvine, CA 92697. E-mail: ekrookma@uci.edu.

DOI:http://dx.doi.org/10.1523/ENEURO.0005-14.2014

Copyright (C) 2014 Krook-Magnuson et al.

This is an open-access article distributed under the terms of the Creative Commons Attribution License Attribution-Noncommercial 4.0 International which permits noncommercial reuse provided that the original work is properly attributed. 


\section{Introduction}

Temporal lobe epilepsy (TLE) is the most common form of epilepsy in adults. Many TLE patients that are unresponsive to anti-epileptic drugs are also not good candidates for surgical resection, leaving a large population of patients with a great and currently unaddressed need for seizure control. On-demand optogenetics (Armstrong et al., 2013) provides a powerful tool to study the potential influence of networks outside the hippocampus on temporal lobe seizures and thereby identify new targets for intervention and improve understanding of network interactions in epilepsy. The cerebellum has been considered as a potential intervention target (Miller, 1992; Fountas et al., 2010), and a recent study indicated that the cerebellum may exert surprisingly potent effects on normal hippocampal information processing (Rochefort et al., 2011). Given the need for new intervention strategies and the specificity achievable with on-demand optogenetics, we asked if on-demand optogenetic intervention targeting the cerebellum could provide seizure control.

Using the unilateral intrahippocampal kainate mouse model of temporal lobe epilepsy and on-line seizure detection (Armstrong et al., 2013), we found that cerebellar targeted intervention can inhibit spontaneous temporal lobe seizures during the chronic phase of the disorder, and that the direction of modulation as well as the location of intervention within the cerebellum can affect the outcome of intervention. While on-demand optogenetic excitation or inhibition of cerebellar parvalbumin (PV)expressing neurons, including Purkinje cells, results in a decrease in seizure duration, a consistent reduction in spontaneous seizure frequency occurs uniquely with ondemand optogenetic excitation of the midline cerebellum. This inhibition of seizure initiation outlasts the duration of intervention and was not seen with intervention directly targeting the hippocampal formation.

\section{Materials and Methods}

\section{Animals}

All animal procedures were performed according to the regulation of the Animal Care Committee at the institution where the research was performed. Mice with restricted opsin expression were generated by crossing mice expressing Cre selectively in parvalbumin-expressing neurons (PV-Cre; B6;129P2-Pvalbtm1(Cre)Arbr/J; stock 008069 from The Jackson Laboratory; Hippenmeyer et al., 2005) with either floxed-STOP channelrhodopsin (ChR2) mice [Ai32; Rosa-CAG-LSLChR2H134R-EYFPdeltaNeo generated by Hongkui Zeng, obtained from the Allen Institute and maintained by crossing with C57BL/6J mice (The Jackson Laboratory stock number 000664); Ai32D is available from The Jackson Laboratory, stock 012569 (Madisen et al., 2012)] or floxed-STOP halorhodopsin (HR) mice (Ai39; B6;129S-Gt(ROSA)26Sortm39 (CAGHOP/EYFP)Hze/J; generated by Hongkui Zeng, available from The Jackson Laboratory, stock 014539 (Madisen et al., 2012), maintained by crossing with C57BL/6J mice). These crosses generated mice expressing $\mathrm{ChR2}$ or HR in PV-containing cells, including cerebellar Purkinje neurons, and are referred to as PV-ChR2 or
PV-HR, respectively, in the text. Obtaining mice with opsin expression restricted to Purkinje neurons was attempted by crossing B6.129-Tg(Pcp2-cre)2Mpin/J [The Jackson Laboratory stock number 004146, a mouse line with Cre inserted into the Pcp2 (Purkinje cell protein 2) gene] with the above Cre-dependent opsin lines. However, as discussed in the Results section, we found this line to have considerable nonspecific expression. The goal of mice with truly restricted expression was instead achieved by crossing a second line (B6.Cg-Tg(Pcp2cre)3555Jdhu/J, The Jackson Laboratory stock number 010536, referred to in the text simply as "Pcp-Cre") with the above Cre-dependent opsin lines.

Male and female offspring were used for experiments. Opsin-negative littermates were used as nonexpressing epileptic controls. For visualization of Cre expression, PV-Cre and Pcp-Cre mice were crossed with a tdTomato reporter strain (B6;129S6-Gt(ROSA)26Sortm9(CAG-tdTomato)Hze/J; stock 007905 from The Jackson Laboratory). For some slices, a DAPI (4',6-diamidino-2phenylindole) mounting media (Vectashield) was used.

\section{Epilepsy induction and monitoring}

To obtain chronically epileptic mice, which reproduce key features of human unilateral hippocampal sclerosis (Cavalheiro et al., 1982; Bragin et al., 1999; Staba et al., 2012), we used the intrahippocampal kainate mouse model of temporal lobe epilepsy, in which kainate is focally injected unilaterally into the hippocampus of adult mice. In this model, after a period of weeks, spontaneous recurrent seizures emerge, which typically originate near the sclerotic region in the hippocampal formation (Bragin et al., 1999; Haussler et al., 2012). On or after postnatal day 46, kainic acid (KA; 50-100 nL, $20 \mathrm{mM}$ in saline, Tocris Bioscience) was stereotaxically injected into the left dorsal hippocampus $(2.0 \mathrm{~mm}$ posterior, $1.25 \mathrm{~mm}$ left, and 1.6 $\mathrm{mm}$ ventral to bregma) under isoflurane anesthesia. At least 2 weeks later, animals were stereotaxically implanted with bipolar, twisted wire, depth electrodes (PlasticsOne) and optical fibers (0.37 NA, 200 or $400 \mu \mathrm{m}$ diameter, ThorLabs) terminated in $1.25 \mathrm{~mm}$ ceramic ferrules (Kientec Systems). Hippocampal optrodes (electrode + optical fiber) were implanted ipsilateral to kainate injection (posterior $2.6 \mathrm{~mm}$, left $1.75 \mathrm{~mm}$, ventral $1.4 \mathrm{~mm}$ with respect to bregma). The hippocampal electroencephalogram (EEG) signal was derived from this single twisted wire electrode (i.e., local hippocampus reference). Cerebellar optical fibers were targeted to the cerebellar surface $5.7 \mathrm{~mm}$ posterior to bregma, at the midline $(0 \mathrm{~mm}$ lateral), $2.3 \mathrm{~mm}$ left, and $2.3 \mathrm{~mm}$ right, or to the medial deep cerebellar nuclei (DCN) at posterior $6.5 \mathrm{~mm}$, lateral $0.6 \mathrm{~mm}$, and ventral $2 \mathrm{~mm}$. A subset of animals additionally had a cerebellar bipolar electrode to record simultaneously the cerebellar EEG signal. As with hippocampal EEG recordings, the cerebellar EEG signal was derived from this single twisted wire electrode (i.e., local cerebellar reference). Implants were fixed to the skull using screws (McMaster-Carr) and dental cement (Teets Cold Curing), and the animals were allowed to recover for several days before beginning $24 \mathrm{~h}$ video and EEG (vEEG) 
monitoring for seizures and subsequent closed-loop seizure detection and light delivery (described in Closedloop seizure detection and light delivery, below). On average, animals were implanted $18.6 \pm 1.8$ weeks after KA injection (range: 2 to 66 weeks) and the effect of light on seizures was examined starting $23 \pm 2.6$ weeks after $\mathrm{KA}$ injection. There was no correlation between seizure duration reduction and time since kainate $p=0.99$, Spearman test).

\section{Closed-loop seizure detection and light delivery}

For vEEG monitoring and on-demand optogenetic intervention, animals were connected via optical patch cords Thorlabs, Doric Lenses; terminated in a $1.25 \mathrm{~mm}$ ferrule that was connected to the implanted optical fiber with a ceramic split sleeve (Precision Fiber Products)] connected through an optical commutator (Doric lenses) to a fibercoupled diode laser (Shanghai Laser \& Optics Century) of an appropriate wavelength to activate the opsin expressed (ChR2: blue $=473 \mathrm{~nm}$; HR: amber $=589 \mathrm{~nm}$ ), and through an electrical commutator (PlasticsOne) to an analog Brownlee 410 amplifier (Armstrong et al., 2013; Krook-Magnuson et al., 2013). EEG signals were digitized by an NI USB-6221-BNC digitizer (National Instruments) sampled at $500-1000 \mathrm{~Hz}$, and analyzed in real-time by a $P C$ running custom MATLAB seizure detection software.

On-line seizure detection was achieved with this custom MATLAB software, a version of which is available for download (Armstrong et al., 2013). Briefly, an experimenter identifies features of the early ictal electrographic signal to be used in triggering the real-time closed-loop seizure detection software and tunes the detector to achieve appropriate seizure detection. The experimenter selects from a number of different inclusion or exclusion criteria and adjusts thresholds to optimally detect the seizures with maximum sensitivity and specificity. The following features can be used alone or in combination to tune the seizure detection algorithm: (1) signal power properties (magnitude, rate of change), (2) spike features (amplitude, width, rate, regularity), (3) signal coastline, and (4) frequency properties (changes in energy within specific frequency bands). Note that a simple spike detection algorithm would be insufficient in this model of epilepsy. As previously described, this real-time seizure detection method, once properly tuned, is able to achieve low false positive and false negative rates (Armstrong et al., 2013; Krook-Magnuson et al., 2013).

Once tuned, the custom closed-loop MATLAB software detects seizures in real-time and triggers the delivery of laser light for $50 \%$ of events in a random fashion, allowing each animal to serve as its own internal control (in addition to opsin-negative littermate controls). Intervention consisted of $3 \mathrm{~s}$ of pulsed light delivery. Both short light pulses (50 ms on, $100 \mathrm{~ms}$ off) and longer pulses (1000 s on, $50 \mathrm{~ms}$ off) were investigated.

\section{Juxtacellular recordings}

In preparation for recordings, mice were implanted with a head bar, and for experiments examining the effect of light on the firing rate of Purkinje neurons, an optical fiber, while under isoflurane anesthesia. Craniotomies $(\sim 1 \mathrm{~mm}$ in diameter) were later placed above the left hippocampus (ipsilateral to previous kainate injection; posterior $2.6 \mathrm{~mm}$, lateral $1.75 \mathrm{~mm}$ ), the left cerebellum (posterior 5.7-6 mm, lateral $2.3 \mathrm{~mm}$ ), and/or the vermis (posterior $5.7-6 \mathrm{~mm}$, midline), also under isoflurane anesthesia. Mice were then transferred to an 8-inch Styrofoam ball levitated by pressurized air and used as a spherical treadmill (Varga et al., 2012). Mice were allowed to recover for a minimum of $1 \mathrm{~h}$ before electrophysiological recordings began. During recordings, mice were freely running or resting on the treadmill. During periods of rest, the mice adjusted their posture, had their eyes open, and occasionally groomed.

Borosilicate glass long-tapered electrodes (Sutter Instruments) were pulled using a micropipette puller (Sutter P1000). An electrode (filled with 0.5 M Na-acetate, 12-20 $\mathrm{M} \Omega$ ) was lowered into either the lateral cerebellum or vermis and was used to record juxtacellularly from cerebellar Purkinje neurons (identified by the presence of complex spikes; example complex spikes are indicated in Figs. 1 and 2). For experiments with dual hippocampal and cerebellar recordings, an additional electrode was filled with $0.5 \mathrm{M} \mathrm{NaCl}$ and lowered into the hippocampus (1100-1400 $\mu \mathrm{m}$ below the dura) to record the hippocampal field potential (referred to in the text as the hippocampal EEG). Recordings were performed using an ELC-03XS universal amplifier (NPI Electronics). Recorded channels were low-pass filtered at $5 \mathrm{kHz}$ and digitized at $20 \mathrm{kHz}$ using NIDAQ data acquisition cards (National Instruments) and the data was recorded using custom-made recording software written in MATLAB (Varga et al., 2012). The animal's movement was continuously video recorded, and video recordings were synchronized with electrophysiological recordings.

For experiments examining the effect of light on Purkinje cells, animals were connected via optical patch cords [Thorlabs, Doric Lenses; terminated in a $1.25 \mathrm{~mm}$ ferrule that was connected to the implanted optical fiber with a ceramic split sleeve (Precision Fiber Products)] connected through an optical commutator (Doric Lenses) to a fiber-coupled diode laser (Shanghai Laser \& Optics Century) of an appropriate wavelength to activate the opsin expressed (ChR2: blue $=473 \mathrm{~nm}$; HR: amber $=589$ $\mathrm{nm})$. Pulsed light delivery was controlled by a function generator. The effect of both short pulses of light $6.67 \mathrm{~Hz}$, $33.3 \%$ duty cycle) and long pulses of light $(1 \mathrm{~Hz}, 80 \%$ duty cycle) were examined.

\section{Slice electrophysiology}

Whole-cell patch-clamp recordings were made from $300-$ $\mu \mathrm{m}$-thick cerebellar slices prepared in ice-cold sucrose solution containing the following (in $\mathrm{mM}$ ): $85 \mathrm{NaCl}, 75$ sucrose, $2.5 \mathrm{KCl}, 25$ glucose, $1.25 \mathrm{NaH}_{2} \mathrm{PO}_{4}, 4 \mathrm{MgCl}$, $0.5 \mathrm{CaCl}_{2}$, and $24 \mathrm{NaHCO}_{3}$. Recordings were done at $36{ }^{\circ} \mathrm{C}$ using artificial cerebrospinal fluid containing (in $\mathrm{mM}): 2.5 \mathrm{KCl}, 10$ glucose, $126 \mathrm{NaCl}, 1.25 \mathrm{NaH}_{2} \mathrm{PO}_{4}, 2$ $\mathrm{MgCl}_{2}$, $2 \mathrm{CaCl}, 26 \mathrm{NaHCO}_{3}$; with intracellular solution containing (in $\mathrm{mM}$ ): 126 potassium gluconate, $4 \mathrm{KCl}, 10$ HEPES, 4 Mg-ATP, $0.3 \mathrm{Na}_{2}$-GTP, 10 phosphocreatine, 8 biocytin; pH 7.2; 270-290 mOsm; pipette resistance: 3-4.5 $\mathrm{M} \Omega$. Slices were visualized with an upright mi- 
Table 1 Statistical table

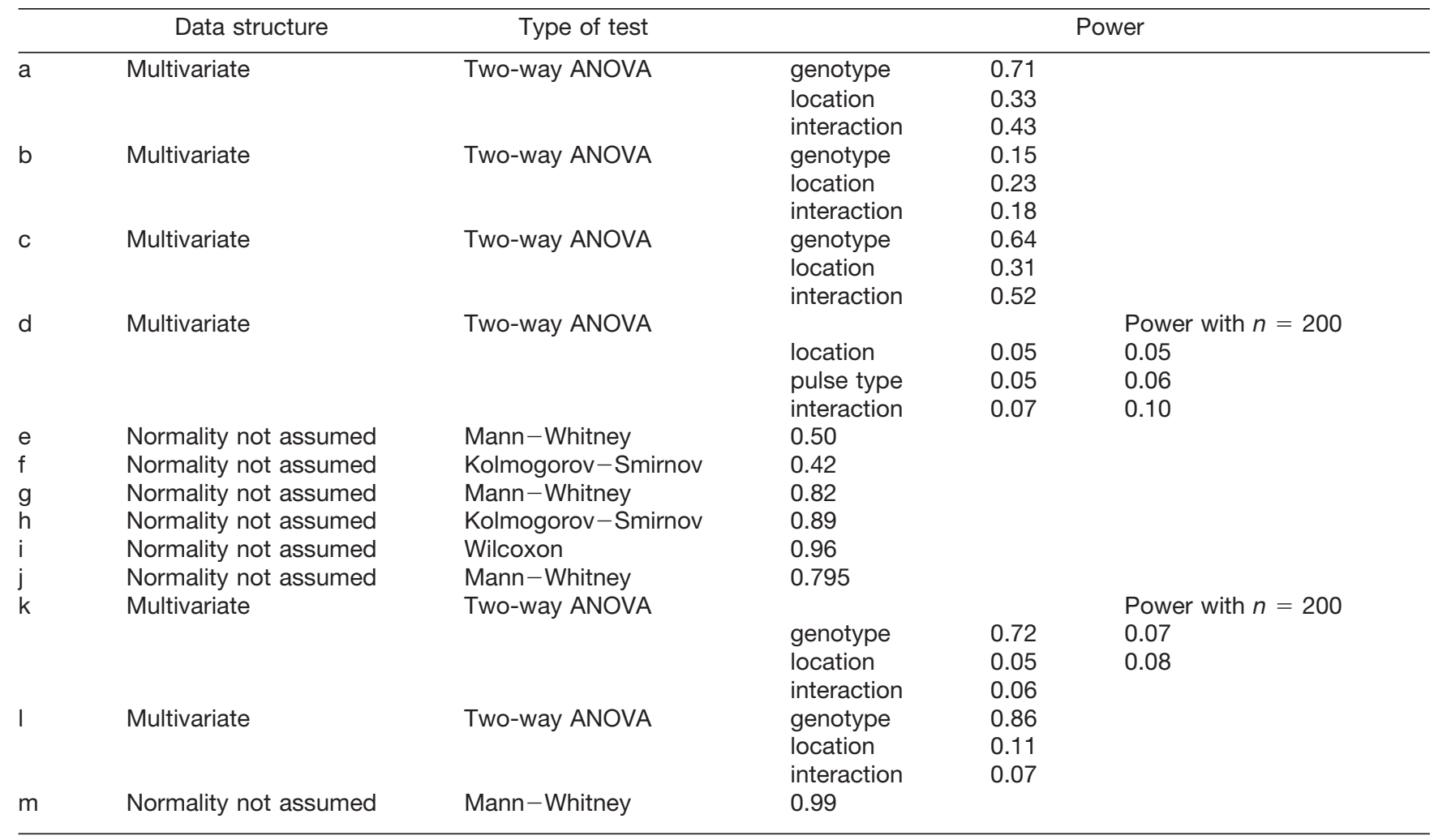

croscope (Eclipse FN-1; Nikon) with infrared (750 nm) Nomarski differential interference contrast optics (Nikon 40× NIR (near infrared) Apo N2 NA0.8W WD3.5 objective with $1.5 \times$ magnification lens). Light was delivered through the epifluorscence port of the Nikon Eclipse FN-1, using a Lambda DG-4 with smart shutter and LAMDA SC controller (Shutter Instruments), and TTL input from a Digidata 1322A (Axon Instruments). After the recordings, slices were fixed in $0.1 \mathrm{M}$ phosphate buffer containing $4 \%$ paraformaldehyde and $0.1 \%$ picric acid at $4{ }^{\circ} \mathrm{C}$. Streptavidin conjugated to Alexa-594 was used to detect biocytin and visualize recorded cells. Large cells in the Purkinje cell layer were targeted for recordings, and all cells included in the analysis were recovered for post hoc analysis and showed Purkinje cell morphology.

\section{Statistical analysis}

Seizure duration after the time of the trigger and time to next seizure were analyzed off-line by reviewers blinded to the light condition and genotype of the animal. On average, $100 \pm 1$ events were analyzed per animal per condition. Comparisons between light and no light conditions for post-detection seizure duration and time to next seizure were compared in each animal using twosample Kolmogorov-Smirnov and two-tailed Man$\mathrm{n}$-Whitney tests. Effects on post-detection seizure duration and time to next seizure (light vs no light) were examined at the group level using Wilcoxon signed ranks test. Comparison between opsin-expressing animals and opsin-negative littermates for percent post-detection sei- zure duration reduction with light, and for percent increase in median time to next seizure with light, was done with a two-tailed Mann-Whitney test. Comparison of percent duration reduction and comparisons of increases in time to next seizure between conditions (Factor A: light location; Factor B: opsin expression) was made using a two-way ANOVA. Data recorded from head-fixed animals was analyzed using custom-written routines in MATLAB using the Signal Processing Toolbox. The juxtacellular recorded signal was high-pass filtered at $400 \mathrm{~Hz}$, and single-unit spikes were detected after crossing a threshold manually set by the experimenter (typically between 200 and $400 \mu \mathrm{V}$ ). Superimposing all detected spikes revealed single units in all cases. The firing rate was determined in 10-100-ms-long windows throughout the recording, and firing rates during ictal and interictal periods, or between no light and light conditions, were compared using Mann-Whitney tests. The calculated average firing rates during intervention included the brief periods of no light between light pulses, and therefore reflect the net change during intervention. One cell recorded from a PV-HR animal was too deep and was excluded from analysis.

Values presented are mean \pm SEM. A $p$ value $<0.05$ was considered significant. Statistical analysis was done using Microsoft Excel 2007, OriginPro 8 and 9, MATLAB, and Google documents. To estimate the power (Table 1) of the Mann-Whitney and the Kolmogorov-Smirnov tests for effects on seizure duration at the individual animal level, we used a sample size of 100 events $(50 \%$ receiving intervention, similar to our actual data sets), a 
desired detectable difference of a $20 \%$ reduction in mean post-detection seizure duration, and assumed gamma distributions for the underlying data. Estimates of the parameters for the gamma distributions for seizure durations of events receiving light and not receiving light were based on a data set showing approximately a $20 \%$ reduction in duration with intervention. Shape $(k)$ was estimated as the mean squared divided by the variance, and spread $(\theta)$ was estimated as variance divided by the mean. The power was then estimated by simulation, using 10,000 randomly generated data sets with the desired sample size and distribution. The power for Mann-Whitney and Kolmogorov-Smirnov tests for time to next seizure at the individual animal level, as well as changes in firing for juxtacellular recordings, was estimated in a similar manner. Power values for two-way ANOVAs are post hoc values, using the actual data sets tested, and should be interpreted as such. For those with a low power (e.g., due to little or no underlying difference), the power based on a sample size of 200 animals is also included in the Table 1 for reference. Power for group level statistics for Mann-Whitney and Wilcoxon tests were estimated via simulation, using 10,000 randomly generated data sets using Gaussian distributions, a desired detectable difference of $30 \%$, our typical group sample size of nine, and a typical standard deviation for these data sets $(20 \%)$.

\section{Results}

\section{Lateral cerebellar intervention in PV-ChR2 animals}

In order to gain optogenetic control over cerebellar neurons, animals expressing Cre in parvalbumin-expressing neurons (PV-Cre), including cerebellar Purkinje cells (Fig. 1a), were crossed with mice expressing the excitatory opsin channelrhodopsin (ChR2) (Boyden et al., 2005; Madisen et al., 2012) in a Cre-dependent fashion (Madisen et al., 2012), as detailed in Materials and Methods, above. Whole-cell patch-clamp recordings from cerebellar slices from PV-ChR2 mice revealed strong light-induced excitatory currents (1580 $\pm 140 \mathrm{pA}, n=14$ Purkinje cells), which were capable of driving Purkinje cells to fire action potentials (Fig. 1b). No currents or depolarization were induced in cells recorded from opsin-negative animals (Fig. 1b). To examine the effect of light delivery on Purkinje cells in vivo, we additionally performed juxtacellular recordings of Purkinje cells in awake animals. The firing rate of Purkinje cells significantly increased during light delivery $[p<0.01$ in 9 of 9 recorded cells with short light pulses; $p<0.01$ in 5 of 6 cells with longer pulses of light; Mann-Whitney ${ }^{\mathrm{m}}$ (superscript refers to line in the Table 1) $81 \pm 21 \%$ and $119 \pm 48 \%$ increase in firing rate, respectively; Fig. 1c,d].

To examine the effect of cerebellar-directed ondemand optogenetic intervention on temporal lobe seizures, the unilateral intrahippocampal kainate mouse model of temporal lobe epilepsy was used. During the chronic phase of the disorder, spontaneous seizures were recorded from the hippocampus and custom-designed software provided on-line seizure detection and closed- loop optogenetic intervention (Armstrong et al., 2013; Krook-Magnuson et al., 2013) (Fig. 1e-g).

Delivery of $3 \mathrm{~s}$ of short pulses of light $(473 \mathrm{~nm} ; 50 \mathrm{~ms}$ on, $100 \mathrm{~ms}$ off) to the lateral cerebellar cortex (lobulus simplex) ipsilateral or contralateral to the site of prior intrahippocampal kainate injection produced a significant reduction in seizure duration (ipsilateral: $33 \pm 9 \%$ seizure duration reduction, $n=12$ animals; Fig. 1g,h; contralateral: $30 \pm 15 \%$ reduction; $n=6$ animals; Fig. 1i; ipsilateral vs contralateral: $p=0.12$; opsin-expressing vs opsinnegative littermate controls: $p<0.05$; interaction: $p=$ 0.21 ; two-way ANOVA ${ }^{\text {a; }}$ Fig. $1 \mathrm{k}$ ). There was no significant change in time to next seizure with light application for either light location (ipsilateral: $18 \pm 10 \%$ increase in median time to next seizure; contralateral: $24 \pm 13 \%$ increase; opsin expressing vs opsin negative: $p=0.36$; ipsilateral vs contralateral: $p=0.21$; interaction: $p=0.45$; two-way ANOVA ${ }^{\text {b) }}$, indicating the absence of a rebound effect, or a long-lasting inhibitory effect on seizures with lateral cerebellar light delivery.

We next examined whether the frequency of light delivery had an effect on seizure control by using $3 \mathrm{~s}$ of pulsed light with longer pulses of light (long: $1000 \mathrm{~ms}$ on, $50 \mathrm{~ms}$ off, rather than the short pulse generally used: 50 $\mathrm{ms}$ on, $100 \mathrm{~ms}$ off). This intervention also inhibited seizures (ipsilateral: $32 \pm 10 \%$ duration reduction; contralateral: $35 \pm 10 \%$ duration reduction; ipsilateral vs contralateral: $p=0.14$; opsin-expressing vs opsinnegative littermate controls: $p<0.05$; interaction: $p=$ 0.27 ; two-way ANOVAc; Fig. 1k). Indeed, long pulses were as efficacious at inhibiting seizure duration as short pulses ( $32 \pm 10 \%$ vs $33 \pm 9 \%$ and $35 \pm 10 \%$ vs $30 \pm 15 \%$, as discussed above; location: $p=0.98$; pulse length: $p=$ 0.87 ; interaction: $p=0.78$; two-way ANOVA $^{d}$ ), indicating that the frequency of light pulses is not a critical factor for inhibiting seizure duration.

Taken together, these data indicate that inhibition of seizure duration is achievable by activating PVexpressing neurons, including Purkinje cells, of either lateral cerebellar hemisphere.

\section{Hippocampal intervention in PV-ChR2 animals}

It has been reported that on-demand activation of hippocampal PV-expressing interneurons can inhibit seizure duration (Krook-Magnuson et al., 2013). We therefore also examined hippocampal-directed intervention in order to directly compare cerebellar to hippocampal intervention. Similar levels of reduction of seizure duration were achieved with these two intervention strategies [3 $\mathrm{s}$ of short pulses, hippocampal intervention: $35 \pm 5 \%$ duration reduction, $p<0.001$, Wilcoxon test', $n=14$ animals; vs opsin-negative controls $p<0.001$, Mann-Whitney'; hippocampal $(35 \pm 5 \%)$ vs lateral cerebellar (32 $\pm 7 \%)$ intervention: $p=0.75$, Mann-Whitneyj]. Intervention targeting the hippocampus with $3 \mathrm{~s}$ of long light pulses also reduced seizure duration (50 $\pm 9 \%$ duration reduction, $p$ $<0.05$ Wilcoxon test'). Hippocampal-directed intervention did not affect time to next seizure (short pulses: $p=$ 0.19 , Wilcoxoni; long pulses: $p=0.19$, Wilcoxon test'), matching previous reports (Krook-Magnuson et al., 2013). 


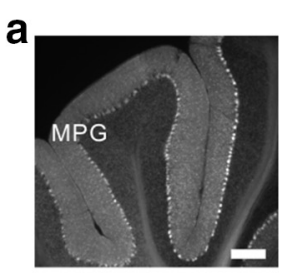

C

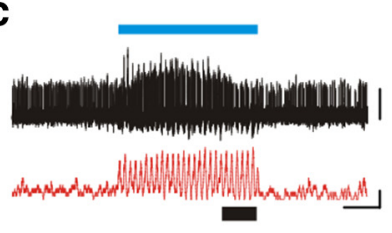

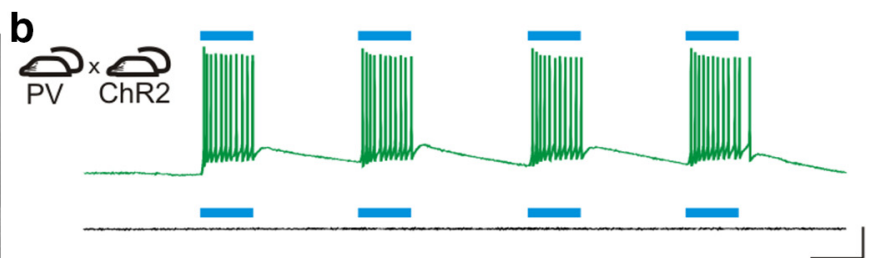

d

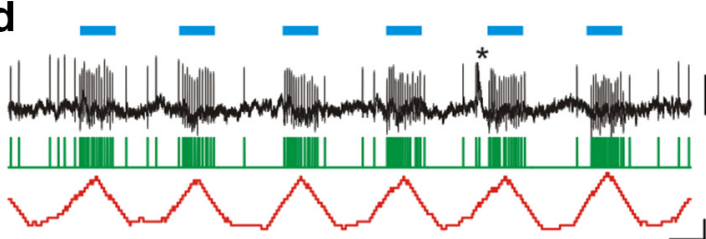

e

$\underset{\text { seizures emerge }}{\stackrel{\text { implant }}{\nabla} \quad \text { closed-loop seizure detection }}$

f

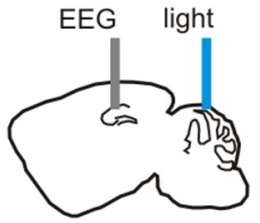

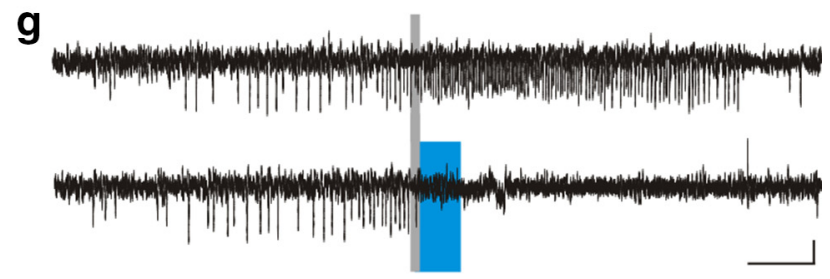

h

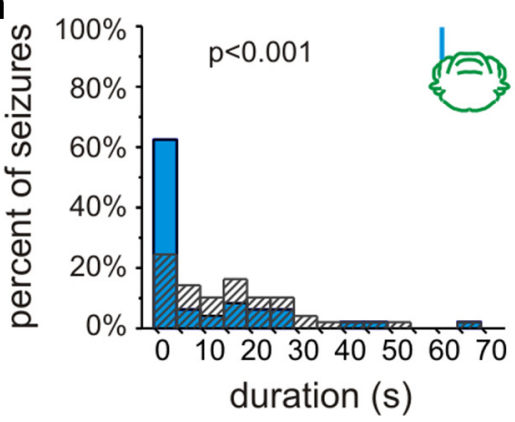

i
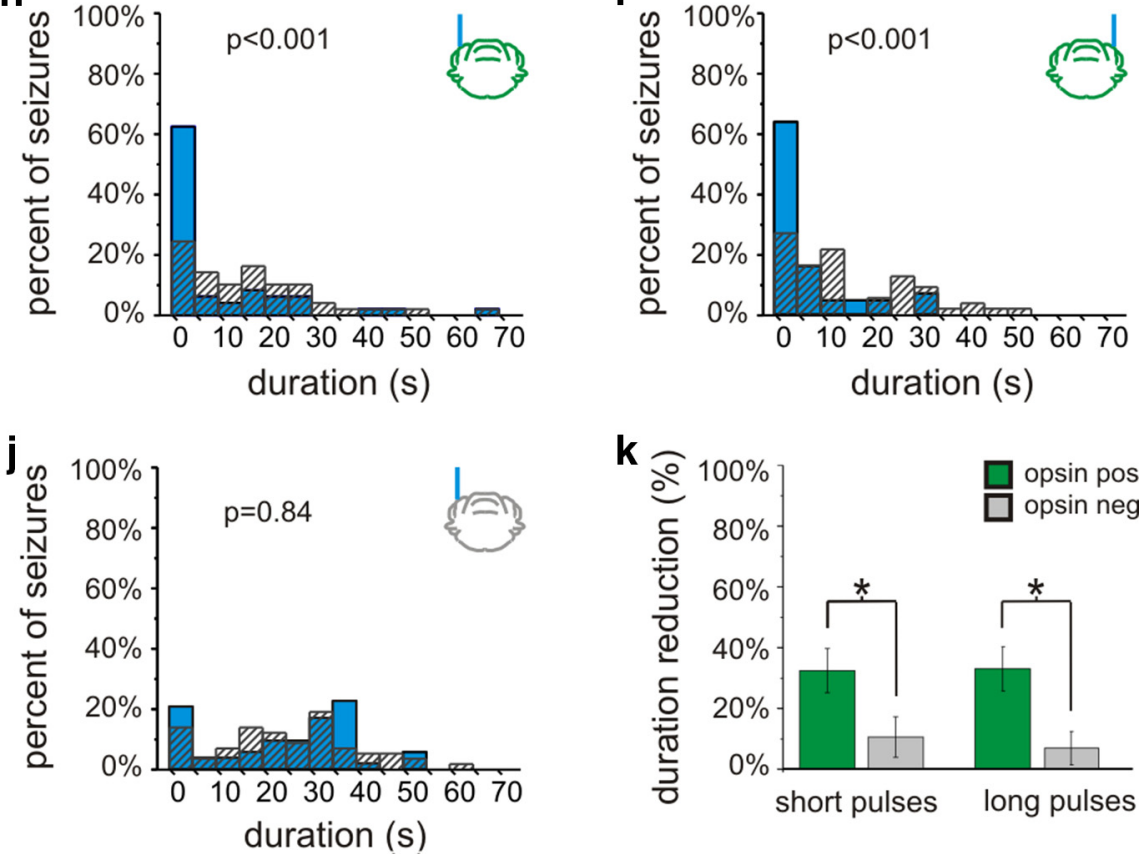

Figure 1 Lateral cerebellar intervention in PV-ChR2 mice. a, In PV-Cre animals, Cre is expressed in cerebellar neurons, including Purkinje neurons. Layers indicated: M, molecular; P, Purkinje; G, granular. $\boldsymbol{b}$, Blue light produces action potentials in Purkinje neurons in PV-ChR2 animals (top) but not in opsin negative animals (bottom trace). c, In vivo juxtacellular recording of a Purkinje cell (black trace), illustrating an increase in firing rate (50 ms sliding window; red trace) with light delivery (blue bar). Portion of trace expanded in $\boldsymbol{d}$ is indicated by a thick black bar. $\boldsymbol{d}$, Detected spikes illustrated by green trace. Asterisk indicates a complex spike. $\boldsymbol{e}$, On-line detection of spontaneous temporal lobe seizures allows on-demand light delivery during the chronic phase of the disorder. $\boldsymbol{f}$, The EEG is recorded from the hippocampus ipsilateral to previous kainate injection (KA), and light is delivered to the cerebellum. $\boldsymbol{g}$, Example detected seizures not receiving light (top trace) and receiving cerebellar directed light-intervention (bottom). Gray bars denote seizure detection. Blue box denotes $3 \mathrm{~s}$ of pulsed light delivery. In opsin-expressing PV-ChR2 animals, light delivered to the ipsilateral $(\boldsymbol{h})$ or contralateral $(\boldsymbol{i})$ cerebellum produces a significant reduction in seizure duration, but there is no effect of light in an opsin-negative animal (j). $\boldsymbol{k}$. Three seconds of pulsed light delivery produces a significant reduction in seizure duration in opsin-expressing animals with both short pulses (50 ms on, $100 \mathrm{~ms}$ off) and long pulses (1000 ms on, $50 \mathrm{~ms}$ off). $* p<0.05$. Scale bars: $a$, 200 $\mu \mathrm{m} ; \boldsymbol{b}, 50 \mathrm{~ms}, 20 \mathrm{~m} \mathrm{~V} ; \boldsymbol{c}, 1 \mathrm{~s} ; 1 \mathrm{mV}$ or $100 \mathrm{~Hz}$ change in firing rate; $\boldsymbol{d}, 50 \mathrm{~ms} ; 1 \mathrm{mV}$ or $100 \mathrm{~Hz}$ change in firing rate; $\boldsymbol{g}, 5 \mathrm{~s}, 0.05 \mathrm{mV}$. 

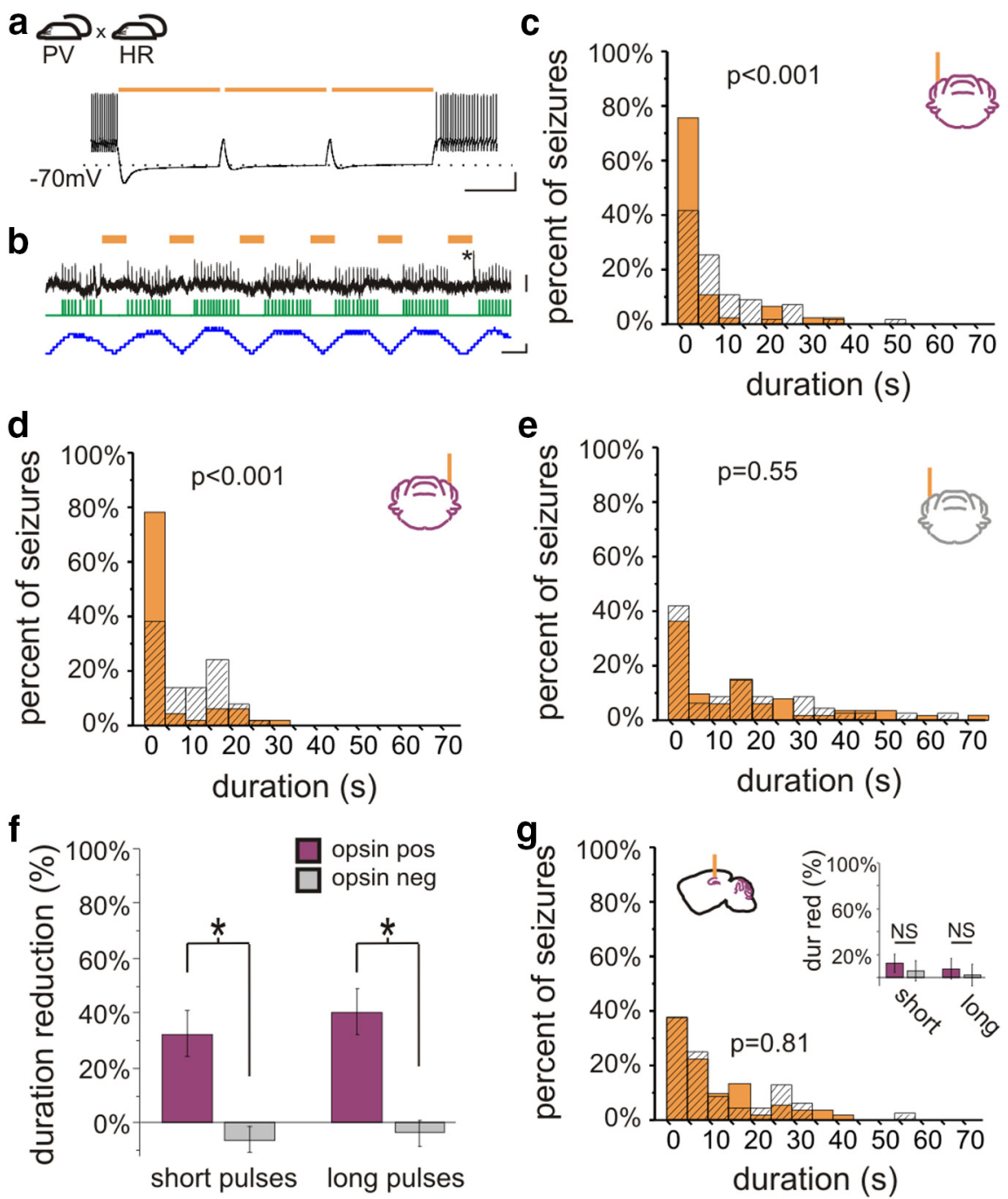

Figure 2 On-demand optogenetic intervention in PV-HR animals. a, Crossing PV-Cre mice with mice expressing in a Cre-dependent manner the inhibitory opsin halorhodopsin (HR) produces mice expressing HR in PV-expressing neurons, including cerebellar Purkinje cells. Light delivery to cerebellar slices from PV-HR mice produces strong inhibition, capable of inhibiting Purkinje cell firing induced by direct current injected. $\boldsymbol{b}$, Light delivery inhibits spontaneous firing of a Purkinje cell recorded juxtacellularly in vivo. Orange bars denote light delivery. Green trace indicates detected spikes. Blue trace illustrates the change in firing frequency (50 ms sliding window). The asterisk marks a complex spike. In vivo on-demand intervention in PV-HR animals directed to the cerebellar cortex ipsilateral (c) or contralateral (d) to previous hippocampal kainate injection reduced postdetection seizure duration in opsinexpressing, but not opsin-negative (e) animals. $\boldsymbol{f}$, Both short and long light pulses were effective at stopping seizures. $\boldsymbol{g}$, In contrast, light delivery to the hippocampus in PV-HR animals did not affect seizure duration. dur red, Duration reduction. Scale bars: $\boldsymbol{a}, 500 \mathrm{~ms}$, $20 \mathrm{mV}$; $\boldsymbol{b}, 50 \mathrm{~ms}$; top, $4 \mathrm{mV}$; bottom, $100 \mathrm{~Hz}$ change in firing rate.

\section{Lateral cerebellar intervention in PV-HR animals}

We next asked if on-demand cerebellar intervention required activation of Purkinje cells per se. That is, can disruption of cerebellar activity in either direction inhibit temporal lobe seizures, or is excitation required? Could inhibition of Purkinje cells actually worsen seizures? To address this, we crossed PV-Cre animals with mice expressing the inhibitory opsin halorhodopsin (HR) (Gradinaru et al., 2010; Madisen et al., 2012) in a Credependent manner (Madisen et al., 2012). Light application to cerebellar slices from PV-HR animals produced robust inhibitory currents in recorded Purkinje cells (1090 $\pm 100 \mathrm{pA}, n=8$ Purkinje cells). This inhibition was sufficient to inhibit action potential firing induced by depolarizing current injection (Fig. 2a). No current or change in membrane potential was induced by light delivery to slices from opsin-negative animals ( $n=9$ Purkinje cells). To examine the effect of light delivery on Purkinje cells in vivo, we additionally performed juxtacellular recordings of Purkinje cells in PV-HR animals, and found that light delivery could significantly reduce Purkinje cell firing rate $(p<0.01$ in 5 of 5 recorded Purkinje cells with short pulses; $p<$ 0.01 in 5 of 5 recorded Purkinje cells with long pulses; Mann-Whitney ${ }^{\mathrm{m}} ; 21 \pm 5 \%$ and $24 \pm 8 \%$ decrease in firing rate, respectively; Fig. 2b). 
We then tested the effect of on-demand light delivery in vivo on spontaneous seizures, as previously done with PV-ChR2 animals. Surprisingly, $3 \mathrm{~s}$ of on-demand cerebellar light $(589 \mathrm{~nm})$ delivery in PV-HR animals also reduced seizure duration. This was true for both short light pulses (ipsilateral cerebellum: $32 \pm 13 \%$ duration reduction; contralateral cerebellum: $33 \pm 11 \%$ duration reduction; opsin expressing vs opsin negative: $p<0.05$; location: $p=0.90$; interaction: $p=0.87$, two-way ANO$V^{\mathrm{k}}$ ) and long light pulses (ipsilateral cerebellum: $37 \pm$ $12 \%$ duration reduction; contralateral cerebellum: $44 \pm$ $12 \%$ duration reduction; opsin expressing vs opsin negative: $p<0.01$; location: $p=0.45$; interaction: $p=0.77$, two-way ANOVA'; Fig. 2c-f). We next asked if there was an effect on time to next seizure with lateral cerebellar targeted intervention in PV-HR animals. Similar to intervention in PV-ChR2 animals, short pulses of light targeting the lateral cerebellum had no effect on time to next seizure (ipsilateral: $p=1$, Wilcoxon'; contralateral: $p=0.64$, Wilcoxon'). These data indicate that inhibition of seizure duration is achievable with long or short pulses targeting either lateral cerebellar hemisphere in PV-HR animals. Therefore, for cerebellar directed intervention, the direction of modulation is not a critical factor for inhibition of seizure duration.

\section{Hippocampal intervention in PV-HR animals}

Given these findings with lateral cerebellar intervention, we next asked if the same would hold for hippocampal directed intervention. While PV-expressing neurons in the cerebellum include the large projection neurons of the cerebellar cortex (i.e., Purkinje cells), in the hippocampus, $\mathrm{PV}$ is not expressed in principal cells. Therefore, inhibition of PV-expressing neurons in the two locations has different effects on the respective networks, and may have different effects on seizure duration. Indeed, we found that on-demand optogenetic inhibition of PV neurons in the hippocampus did not affect seizure duration, regardless of pulse duration (opsin-expressing vs opsin negative, short pulses: $p=0.73$, Mann-Whitney; long pulses: $p=0.70$, Mann-Whitney'; Fig. 2g). There was also no effect on time to next seizure (light vs no light, short pulses: $p=0.50$, Wilcoxoni; light vs no light, long pulses: $p=1$; Wilcoxon'). Note that intervention was of limited duration ( $3 \mathrm{~s}$ of pulsed light). This indicates that whether the direction of modulation (i.e., excitation or inhibition) is a critical factor in inhibiting seizure duration depends on the underlying circuitry (e.g., alteration of local inhibitory neurons vs altering activity of inhibitory output neurons at a distant site), with inhibition of seizure duration in PV-HR animals occurring with cerebellar-, but not hippocampal-, directed intervention.

\section{Intervention directed to the midline cerebellum}

While interventions in which light was delivered to the hippocampus or lateral cerebellum did not consistently affect the frequency of seizures, when light $(3 \mathrm{~s}$, short pulses) was instead delivered to the midline cerebellum (targeting the vermis) in PV-ChR2 animals, in addition to a reduction in seizure duration (39 $\pm 14 \%$ duration reduction $p<0.05$, Wilcoxon'; $n=7$ animals; Fig. 3a), there was a significant and consistent prolongation of the interseizure interval $(175 \pm 64 \%$ increase in time to next seizure; $p<0.05$, Wilcoxon'; at the individual animal level, significant in 6 of 7 animals, $p<0.05$, Mann-Whitney ${ }^{\mathrm{e}}$ ), a therapeutically desirable outcome. This inhibition of seizure generation outlasted the duration of the applied light (Fig. 3b) and, for short pulses, was unique to vermal intervention (Fig. 3c). Vermal-directed intervention with long pulses also increased time to next seizure (363 \pm $92 \%$ increase; $p<0.05$ Wilcoxoni; $^{\mathrm{i}}$ at the individual animal level, significant in 6 of 7 animals, $p<0.05$, MannWhitneye).

We next asked whether the effect on seizure frequency required excitation of $\mathrm{PV}$ cells per se, or whether disruption of vermal cerebellar activity alone could alter seizure frequency, similar to effects on seizure duration. We therefore examined the effect of midline cerebellar light delivery in PV-HR animals. Light delivery $(589 \mathrm{~nm})$ produced no significant effect on time to next seizure, regardless of pulse duration (percent change time to next seizure, short pulses: $-10 \pm 7 \%, p=0.15$, Wilcoxon ${ }^{i}, n$ $=8$ animals; Fig. $3 \mathrm{c}$; long pulses: $-2 \pm 15 \% ; p=0.64$, Wilcoxoni). These findings indicate that a disruption of cerebellar activity alone is not sufficient to cause a decrease in seizure frequency. Rather, the direction of modulation (excitation), as well as the location of light delivery (vermis), are critical to achieve a consistent reduction in seizure frequency (Fig. 3c).

Purkinje neurons project to the deep cerebellar nuclei (DCN). In separate experiments, we therefore targeted light delivery ( $3 \mathrm{~s}$, short pulses) to the axon terminals of Purkinje neurons in the medial DCN (fastigial nucleus, which receives input from the medial cerebellar cortex). Targeting light delivery to the DCN in PV-ChR2 animals decreased seizure duration $(27 \pm 16.1 \%$ reduction $)$ and, importantly, also increased time to next seizure (361 $\pm 110 \%$ increase; $p<0.01$ in 5 of 5 animals; Mann-Whitney ${ }^{\mathrm{e}}$; vs midline cerebellar cortex: $p=0.19$, Mann-Whitneyj).

\section{Selective excitation of Purkinje cells}

Purkinje cells not only express PV (and thus the opsins in PV-ChR2 and PV-HR animals) but also are the sole output of the cerebellar cortex. Therefore, any intervention targeting the cerebellar cortex will ultimately have its effect through an alteration of Purkinje cell firing. Still, other neurons in the cerebellum express PV, and we therefore sought to replicate our key findings in a mouse line expressing opsins selectively in Purkinje cells. Therefore, we tested the effect of cerebellar intervention using B6.129$\mathrm{Tg}(\mathrm{Pcp} 2-\mathrm{cre}) 2 \mathrm{Mpin} / \mathrm{J}-\mathrm{ChR} 2$ animals. While we replicated an effect on seizure duration (percent duration reduction ipsilateral: $91 \%, p<0.0000001, n=1$ animal, Kolmogorov - Smirnov $^{\mathrm{h}}$ and Mann-Whitney'; contralateral: $82 \%$, $p<0.0000001, n=1$ animal, Kolmogorov - Smirnov $^{\mathrm{h}}$ and Mann-Whitney ${ }^{g}$ ) and time to next seizure with vermal intervention (percent increase time to next vermis: $66 \%, p$ $<0.001, n=1$ animal, Mann-Whitney ${ }^{\mathrm{e}}$; ipsilateral: $p=$ 0.37 , Mann-Whitney ${ }^{\mathrm{e}}$; contralateral: $p=0.34$, Man$\mathrm{n}-$ Whitney $^{\mathrm{e}}$ ), we found that expression was not selective. 
a

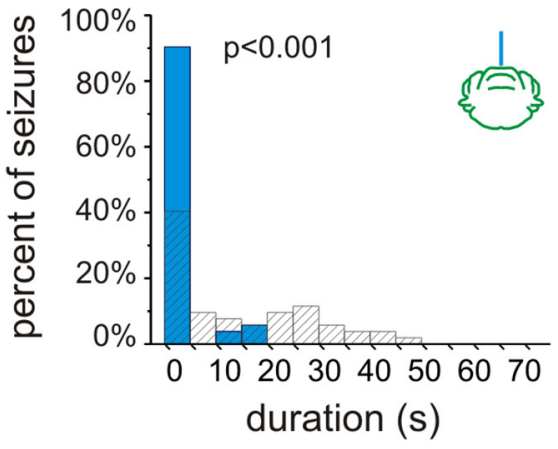

C$$
\text { C }
$$

b

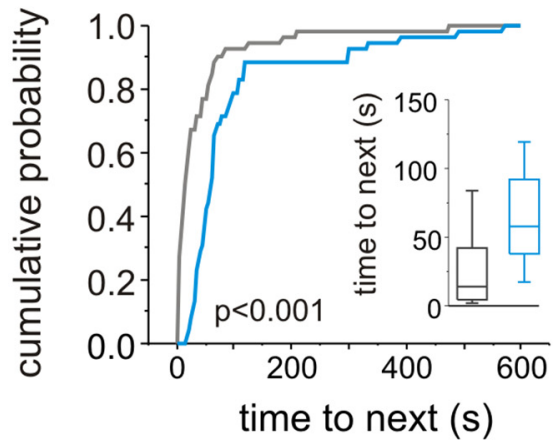

Figure 3 Optogenetic intervention targeting the midline cerebellum. On-demand optogenetic intervention with $3 \mathrm{~s}$ of pulsed light delivered to the midline cerebellum (vermis) in a PV-ChR2 mouse reduces seizure duration (a) and increases time to next seizure (b). Blue bars and traces indicate events receiving light. Gray indicates events not receiving light. Inset, Box and whisker plot indicating median, 25th and 75th percentiles, and 25th and 75th percentile \pm 1.5 times the interquartile range. $\boldsymbol{c}$, With $3 \mathrm{~s}$ of short light pulses (50 ms on, $100 \mathrm{~ms}$ off), there is an increase in time to next seizure with vermal directed intervention in PV-ChR2 animals. CB, Cerebellum; hipp, hippocampus; ipsilat or ipsi, ipsilateral to KA; contrlat, contralateral.

Crossing B6.129-Tg(Pcp2-cre)2Mpin/J with a tdTomato reporter strain revealed Cre expression in Purkinje cells, as well as in cerebellar molecular layer interneurons, deep cerebellar neurons, scattered cerebral cortex neurons, and even some hippocampal granule cells (data not shown).

We therefore obtained a second line (B6.Cg- $\mathrm{Tg}(\mathrm{Pcp} 2-$ cre) $3555 \mathrm{Jdhu} / \mathrm{J}$; referred to here as "Pcp-Cre"), which we found to be highly specific (Fig. 4a). We performed wholecell patch-clamp recordings from Purkinje neurons from cerebellar slices from Pcp-ChR2 animals. Light delivery produced strong excitatory currents $(2040 \pm 140 \mathrm{pA}, n=$
6 Purkinje cells), capable of inducing Purkinje cell firing (Fig. 4b). We then tested in vivo on-demand optogenetic intervention in Pcp-ChR2 animals. As in PV-ChR2 animals, cerebellar light delivery significantly reduced seizure duration (percent duration reduction ipsilateral: $46 \pm$ $15 \%, n=4$ animals, $p<0.05$ in 4 of 4 , Kolmogoro$\mathrm{v}-$ Smirnov $^{\mathrm{h}}$ and 3 of 4 Mann-Whitney ${ }^{\mathrm{g}}$; contralateral: 49 $\pm 9 \%, n=4$ animals, $p<0.05$ in 4 of 4 , Kolmogoro$v-$ Smirnov $^{\mathrm{h}}$ and Mann-Whitney ${ }^{\mathrm{g}}$; vermis: $42 \pm 9 \%, n=$ 6 animals; $p<0.05$ in 6 of 6 , Kolmogorov - Smirnov $^{h}$ and Mann-Whitney'; Fig. 4c,e). As opsins are not expressed in the hippocampus in Pcp-ChR2 animals, we predicted 


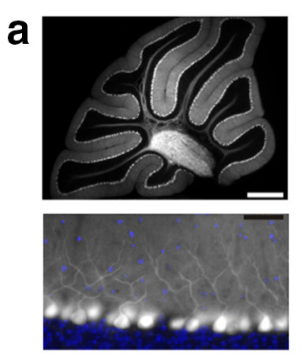

C

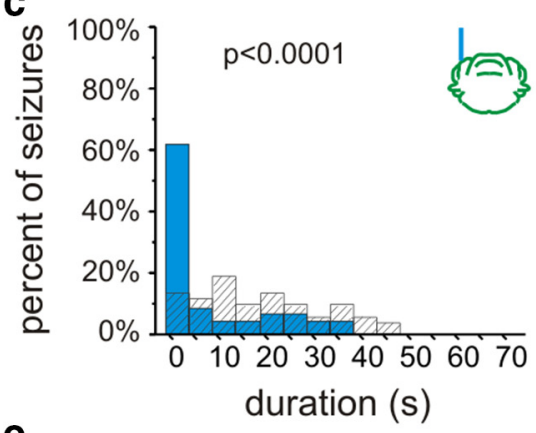

e

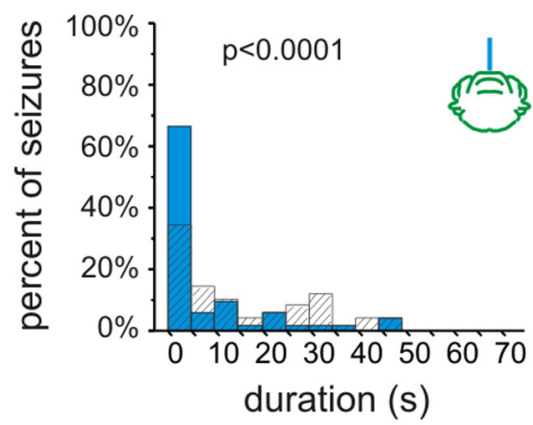

b $\underset{\mathrm{Pcp}}{\underset{\mathrm{ChR2}}{\overparen{2}}}$

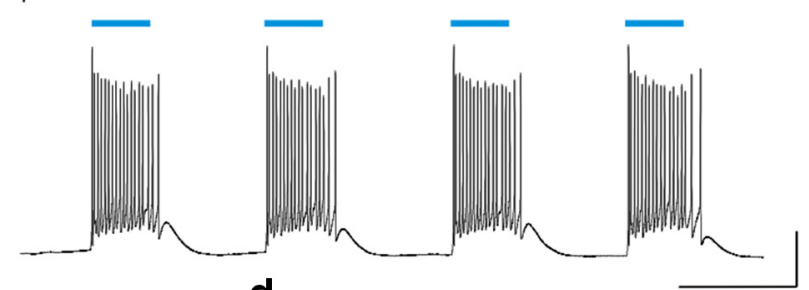

d

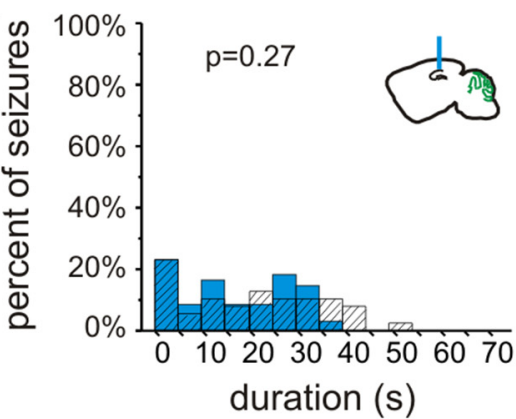

$\mathbf{f}$

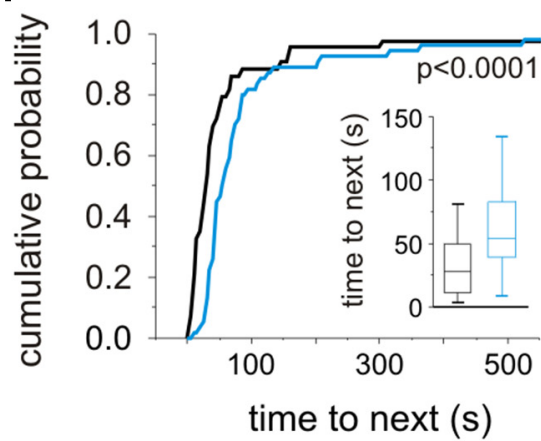

Figure 4 On-demand optogenetic intervention with Purkinje cell specific expression. $\boldsymbol{a}$, In Pcp-Cre mice, cerebellar Cre is selectively expressed in Purkinje neurons. Cre expression (white) was visualized by crossing with a reporter strain. Bottom, blue, DAPI fluorescent stain. $\boldsymbol{b}$, Crossing Pcp-Cre mice with mice expressing ChR2 in a Cre-dependent manner produces mice with ChR2 expressed selectively in Purkinje neurons. Light delivery to cerebellar slices from Pcp-ChR2 animals induces firing in Purkinje neurons. $\boldsymbol{c}$, In vivo on-demand optogenetic intervention targeting the lateral cerebellum produces an inhibition of seizure duration. $\boldsymbol{d}$, Light delivery to the hippocampus (which does not express opsin in Pcp-ChR2 animals) does not inhibit seizures. Light delivery to the midline cerebellum is capable of reducing seizure duration (e) and increasing time to next seizure $(\boldsymbol{f})$. Scale bars: $\boldsymbol{a}$, top, $500 \mu \mathrm{m}$; bottom, $50 \mu \mathrm{m} ; \boldsymbol{b}, 100 \mathrm{~ms}, 20 \mathrm{mV}$.

no change in seizure duration with hippocampal light delivery. Indeed, in Pcp-ChR2 animals, hippocampal light delivery produced no significant change in seizure duration $(p=0.15$, Wilcoxon'; Fig. $4 \mathrm{~d}$; cerebellar vs hippocampal intervention, $p<0.05$, Mann-Whitney'). These data indicate that direct optogenetic modulation of cerebellar Purkinje cells alone is sufficient to reduce spontaneous temporal lobe seizure duration.

We next examined the effect on seizure frequency of midline cerebellar light delivery in animals with Purkinjecell-selective ChR2 expression. Intervention targeting the vermis in Pcp-ChR2 animals was able to significantly increase the time to next seizure (long pulses: $p<0.05$ in 4 of 5 animals, Kolmogorov-Smirnov ${ }^{f}$ and Mann-Whitney'; Fig. 4f; short pulses: $p<0.05$ in 2 of 6 animals, Kolmogoro$v-$ Smirnov $^{f}$ and Mann-Whitney ${ }^{\mathrm{e}}$ ). These data therefore support that selective optogenetic excitation of cerebellar Purkinje neurons is capable of not only reducing seizure duration, but also of inhibiting seizure induction (i.e., increasing time to next seizure).

\section{Bidirectional functional connectivity}

The above data demonstrate that cerebellar activity can modulate hippocampal activity, in that cerebellardirected intervention can inhibit hippocampally recorded temporal lobe seizures. We additionally find that temporal lobe seizures can modulate cerebellar activity: in 17 of 24 animals, temporal lobe seizures produced a change in cerebellar EEG (Fig. 5a,b). In a subset of these animals, we recorded from Purkinje neurons (identified by the presence of complex spikes) using the juxtacellular method from awake, head-fixed animals (Varga et al., 2012). Temporal lobe seizures significantly modulated $\left(p<0.01\right.$, Mann-Whitney $\left.{ }^{\mathrm{m}}\right)$ the firing of seven of 21 recorded Purkinje cells (Fig. 5c,d). These findings indicate that not only can the cerebellum affect 


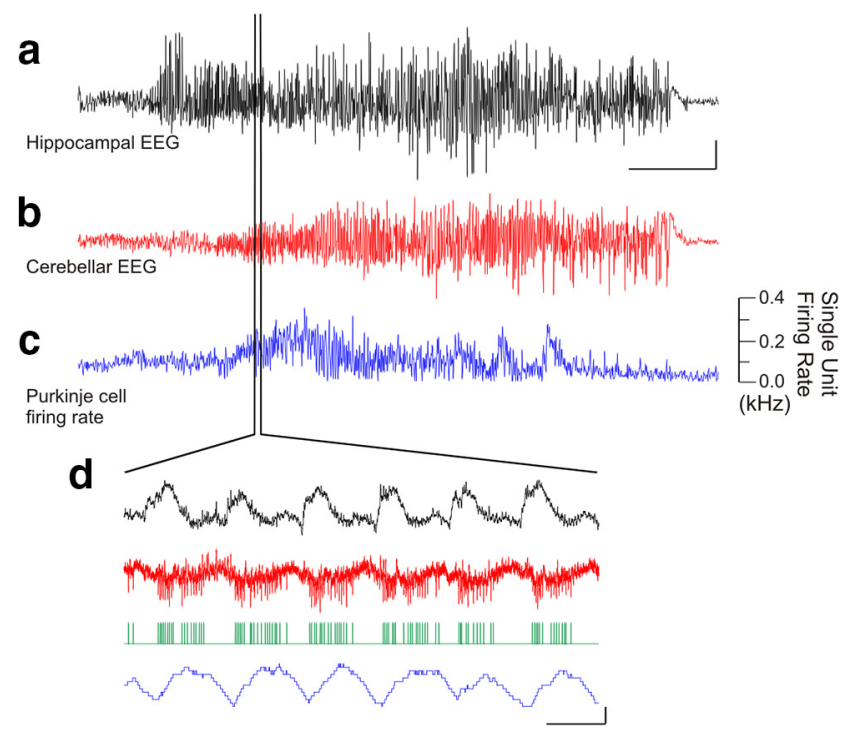

Figure 5. Temporal lobe seizures modulate cerebellar activity. An example temporal lobe seizure recorded in the hippocampus (a), which produced changes in the cerebellar EEG (b) and in the firing rate of a juxtacellularly recorded Purkinje cell over the course of the seizure (c) as well as on a shorter time scale (d). Green trace denotes detected Purkinje cell spikes. Scale bars: a, $1 \mathrm{mV} ; \boldsymbol{b}, 0.5 \mathrm{mV} ; \boldsymbol{a}-\boldsymbol{c}, 10 \mathrm{~s} ; \boldsymbol{d}, 0.5 \mathrm{mV}$ or $0.1 \mathrm{kHz}$ change in firing rate, $0.1 \mathrm{~s}$.

temporal lobe seizures, but that temporal lobe seizures can also affect cerebellar activity; that is, there is a bidirectional functional connectivity.

\section{Discussion}

We demonstrate that cerebellar-directed intervention can inhibit temporal lobe seizures, that temporal lobe seizures can modulate cerebellar activity, and that excitation of midline cerebellar Purkinje neurons produces a decrease in seizure frequency (increase in time to next seizure). As this inhibition of seizure frequency was seen with only certain interventions, it reveals a fundamentally novel dissociation of an inhibition of on-going seizure events and an inhibition of seizure generation. Additionally, our findings are critically important from a clinical perspective, as they demonstrate that interventions targeting the cerebellum as a potential therapy for medically intractable epilepsies should be revisited.

While the cerebellum is not typically considered in temporal lobe epilepsy, there is certainly precedent for consideration of the cerebellum in epilepsies, including as a potential intervention target. For example, while relatively uncommon, seizures can arise from the cerebellum (for example, with cerebellar tumors) (Harvey et al., 1996; Mesiwala et al., 2002; Norden and Blumenfeld, 2002). Additionally, there are reports of changes in cerebellar blood flow, EEG, and unit activity during seizures (Niedermeyer and Uematsu, 1974; Gartside, 1979; Miller, 1992; Kandel and Buzsaki, 1993; Kottamasu, 1997; Blumenfeld et al., 2009). Importantly, previously there was also considerable interest in the cerebellum as a potential target to curtail seizures.
However, animal studies, largely completed in the 1970s, produced mixed results, with various studies showing no effect, inhibition of, or a worsening of epileptiform activity (Cooke and Snider, 1955; Iwata and Snider, 1959; Dow et al., 1962; Mutani, 1967; Reimer et al., 1967; Mutani et al., 1969; Grimm et al., 1970; Hutton et al., 1972; Babb et al., 1974; Wada, 1974; Hablitz et al., 1975; Maiti and Snider, 1975; Snider and Maiti, 1975a,b; Hablitz, 1976; Hemmy et al., 1977; Bantli et al., 1978; Strain et al., 1978, 1979; Lockard et al., 1979; Snider, 1979; Ebner et al., 1980; Godlevskii et al., 2004). This variability may be due in part to the lack of specificity inherent with electrical stimulation or hyperthermia, and may have contributed to the decrease in interest in the cerebellum by epilepsy researchers. Importantly, on-demand optogenetics provides improved specificity of intervention. Our results demonstrate not only that the cerebellum can be an effective target for inhibition of temporal lobe seizures, but also that both the location of intervention and the direction of modulation (i.e., excitation or inhibition) can affect seizure control.

Electrical stimulation of the cerebellum has also been examined in a number of relatively small human trials (Cooper et al., 1973; Sramka et al., 1976; Van Buren et al., 1978; Levy and Auchterlonie, 1979; Wright et al., 1984; Davis and Emmonds, 1992; Chkhenkeli et al., 2004; Velasco et al., 2005). Again, however, results have been mixed. This may be due to variability in patient populations, small sample sizes (making statistical significance more difficult to achieve), and variability in stimulation parameters (for a review, including some of the complicating factors, see Fountas et al., 2010). A recent Cochrane review of three trials of cerebellar stimulation (Van Buren et al., 1978; Wright et al., 1984; Velasco et al., 2005) found that there was simply insufficient evidence to make conclusive statements on the efficacy of cerebellar stimulation (Sprengers et al., 2014). The mixed results in human studies has also contributed to the weakened enthusiasm for the potential of cerebellar-directed intervention, and despite the continued listing of the cerebellum as a potential target in reviews of electrical stimulation for epilepsy (Theodore and Fisher, 2004; Morrell, 2006; Boon et al., 2007; Karceski, 2007; Krauss and Koubeissi, 2007; Ellis and Stevens, 2008; Hamani et al., 2009; Lockman and Fisher, 2009; Saillet et al., 2009; Wyckhuys et al., 2009; Kahane and Depaulis, 2010; Lega et al., 2010; Rahman et al., 2010; Zhong et al., 2011; Tykocki et al., 2012; Fisher, 2013; Ge et al., 2013; Fisher and Velasco, 2014; Laxpati et al., 2014), relatively little recent experimental work has actually examined this topic. While our results clearly support renewed interest in the cerebellum as a potential intervention target, future translational success will require identifying the appropriate population for this intervention (e.g., perhaps patients with temporal lobe epilepsy), the appropriate location for intervention (e.g., the midline), the appropriate stimulation parameters (e.g., to activate, rather than inhibit, the midline), an appropriate sample same size, improvements in surgical procedures including device 
implantation (to avoid electrode migration), and possibly the implementation of an on-demand, responsive system to control the timing of intervention (Fountas et al., 2010; Rahman et al., 2010; Armstrong et al., 2013; Heck et al., 2014; Sprengers et al., 2014).

Given the specificity achievable with optogenetics, there is currently considerable interest in the use of optogenetics to study seizures and epilepsy (Tonnesen et al., 2009; Wykes et al., 2012; Armstrong et al., 2013; Krook-Magnuson et al., 2013, 2014; Osawa et al., 2013; Paz et al., 2013; Sukhotinsky et al., 2013; Berglind et al., 2014; Chiang et al., 2014). While the findings reported here could not be predicted from earlier optogenetic studies, they are certainly in line with studies indicating that the cerebellum has powerful effects on upper brain centers beyond classical motor control in both health and disease (Ivry and Baldo, 1992; Strick et al., 2009; Grimaldi and Manto, 2012; Buckner, 2013) (note, however, that this concept of a role for the cerebellum beyond motor control is also not without controversy; for example, see Glickstein, 2007). Recent work has demonstrated a cerebellar role in hippocampal spatial navigation (Rochefort et al., 2011) and disturbances in cognitive functions related to autism (Tsai et al., 2012). As in these recent studies, the precise circuits mediating the cerebellar effects on temporal lobe seizures are not yet understood. The cerebellum has many downstream targets, and plausible pathways for the robust, cerebellar-hippocampal seizure regulatory effects described here may involve the ventral lateral, central lateral, or mediodorsal thalamic nuclei (Haroian et al., 1981; Angaut et al., 1985; Bertram et al., 2008; Rochefort et al., 2013; Sinjab et al., 2013; Cavdar et al., 2014), the reticular formation (Anand et al., 1959; Elisevich et al., 1985; Verveer et al., 1997), the hypothalamus (Anand et al., 1959; Zhu et al., 2006; Soussi et al., 2014), the superior colliculus (Gale et al., 1993; Katoh and Benedek, 2003), and (directly or indirectly) the septum, amygdala, or hippocampus itself (Anand et al., 1959; Harper and Heath, 1973; Paul et al., 1973; Heath and Harper, 1974; Maiti and Snider, 1975; Snider and Maiti, 1976; Heath et al., 1978, 1980; Newman and Reza, 1979). For example, electrical stimulation of cerebellar cortex or deep cerebellar nuclei can produce evoked potentials in the hippocampus, which has been interpreted as a direct connection (Heath and Harper, 1974) or an indirect connection (e.g., via the reticular formation; Anand et al., 1959). Heath and Harper (1974) also report anatomical evidence for a direct connection, in the form of degenerating fibers in the hippocampus following lesion of the fastigial cerebellar nucleus, but this has yet to be demonstrated using more modern neuroanatomical methods (Strick et al., 2009; Rochefort et al., 2013). Similarly, there may be connections from the hippocampus to the cerebelIum (Maiti and Snider, 1975; Klemm et al., 1979; Liu et al., 2012). While considerable progress clearly needs to be made in fully understanding the pathways involved in cerebellar-hippocampal interactions, our findings illustrate that this bidirectional functional connectivity can have significant consequences.
Given the prevalence of TLE, the major negative side effects of current treatment options, and the high percentage of patients with uncontrolled seizures, the need for new therapeutic approaches is clear, and our data provide strong support for reevaluation of cerebellar targeted intervention to control temporal lobe seizures.

\section{References}

Anand BK, Malhotra CL, Singh B, Dua S (1959) Cerebellar projections to limbic system. J Neurophysiol 22:451-457. Medline

Angaut P, Cicirata F, Serapide F (1985) Topographic organization of the cerebellothalamic projections in the rat: an autoradiographic study. Neuroscience 15:389-401. Medline

Armstrong C, Krook-Magnuson E, Oijala M, Soltesz I (2013) Closedloop optogenetic intervention in mice. Nat Protoc 8:1475-1493. CrossRef Medline

Babb TL, Mitchell AG Jr, Crandall PH (1974) Fastigiobulbar and dentatothalamic influences on hippocampal cobalt epilepsy in the cat. Electroencephalogr Clin Neurophysiol 36:141-154. Medline

Bantli H, Bloedel JR, Anderson G, McRoberts R, Sandberg E (1978) Effects of stimulating the cerebellar surface on the activity in penicillin foci. J Neurosurg 48:69-84. CrossRef Medline

Berglind F, Ledri M, Sorensen AT, Nikitidou L, Melis M, Bielefeld P, Kirik D, Deisseroth K, Andersson M, Kokaia M (2014) Optogenetic inhibition of chemically induced hypersynchronized bursting in mice. Neurobiol Dis 65:133-141. CrossRef Medline

Bertram EH, Zhang D, Williamson JM (2008) Multiple roles of midline dorsal thalamic nuclei in induction and spread of limbic seizures. Epilepsia 49:256-268. CrossRef Medline

Blumenfeld $\mathrm{H}$, Varghese GI, Purcaro MJ, Motelow JE, Enev M, McNally KA, Levin AR, Hirsch LJ, Tikofsky R, Zubal IG, Paige AL, Spencer SS (2009) Cortical and subcortical networks in human secondarily generalized tonic-clonic seizures. Brain 132:999-1012. CrossRef Medline

Boon P, De Herdt V, Vonck K, Van Roost D (2007) Clinical experience with vagus nerve stimulation and deep brain stimulation in epilepsy. Acta Neurochir Suppl 97:273-280. Medline

Boyden ES, Zhang F, Bamberg E, Nagel G, Deisseroth K (2005) Millisecond-timescale, genetically targeted optical control of neural activity. Nat Neurosci 8:1263-1268. CrossRef Medline

Bragin A, Engel J, Jr., Wilson CL, Vizentin E, Mathern GW (1999) Electrophysiologic analysis of a chronic seizure model after unilateral hippocampal KA injection. Epilepsia 40:1210-1221. Medline

Buckner RL (2013) The cerebellum and cognitive function: 25 years of insight from anatomy and neuroimaging. Neuron 80:807-815. CrossRef Medline

Cavalheiro EA, Riche DA, Le Gal La Salle G (1982) Long-term effects of intrahippocampal kainic acid injection in rats: a method for inducing spontaneous recurrent seizures. Electroencephalogr Clin Neurophysiol 53:581-589. Medline

Cavdar S, Ozgur M, Uysal SP, Amuk OC (2014) Motor afferents from the cerebellum, zona incerta and substantia nigra to the mediodorsal thalamic nucleus in the rat. J Integrative Neurosci. Advance online publication. doi:10.1142/S0219635214500198.

Chiang CC, Ladas TP, Gonzalez-Reyes LE, Durand DM (2014) Seizure suppression by high frequency optogenetic stimulation using in vitro and in vivo animal models of epilepsy. Brain Stim. Advance online publication. doi:10.1016/j.brs.2014.07.034.

Chkhenkeli SA, Sramka M, Lortkipanidze GS, Rakviashvili TN, Bregvadze E, Magalashvili GE, Gagoshidze T, Chkhenkeli IS (2004) Electrophysiological effects and clinical results of direct brain stimulation for intractable epilepsy. Clin Neurol Neurosurg 106: 318-329. CrossRef Medline

Cooke PM, Snider RS (1955) Some cerebellar influences on electrically-induced cerebral seizures. Epilepsia 4:19-28. Medline

Cooper IS, Amin I, Gilman S (1973) The effect of chronic cerebellar stimulation upon epilepsy in man. Trans Am Neurol Assoc 98:192196. Medline 
Davis R, Emmonds SE (1992) Cerebellar stimulation for seizure control: 17-year study. Stereotact Funct Neurosurg 58:200-208. Medline

Dow RS, Fernandez-Guardiola A, Manni E (1962) The influence of the cerebellum on experimental epilepsy. Electroencephalograph Clin Neurophysiol 14:383-398. Medline

Ebner TJ, Bantli H, Bloedel JR (1980) Effects of cerebellar stimulation on unitary activity within a chronic epileptic focus in a primate. Electroencephalograph Clin Neurophysiol 49:585-599. Medline

Elisevich KV, Hrycyshyn AW, Flumerfelt BA (1985) Cerebellar, medullary and spinal afferent connections of the paramedian reticular nucleus in the cat. Brain Res 332:267-282. Medline

Ellis TL, Stevens A (2008) Deep brain stimulation for medically refractory epilepsy. Neurosurg Focus 25:E11. CrossRef Medline

Fisher RS (2013) Deep brain stimulation for epilepsy. Handb Clin Neurol 116:217-234. CrossRef Medline

Fisher RS, Velasco AL (2014) Electrical brain stimulation for epilepsy. Nat Rev Neurol 10:261-270. CrossRef Medline

Fountas KN, Kapsalaki E, Hadjigeorgiou G (2010) Cerebellar stimulation in the management of medically intractable epilepsy: a systematic and critical review. Neurosurg Focus 29:E8. CrossRef Medline

Gale K, Pazos A, Maggio R, Japikse K, Pritchard P (1993) Blockade of GABA receptors in superior colliculus protects against focally evoked limbic motor seizures. Brain Res 603:279-283. Medline

Gartside IB (1979) The activity of cerebellar neurones during epileptiform activity induced by penicillin in the cerebral cortex of the rat. Electroencephalogr Clin Neurophysiol 46:189-196. Medline

Ge Y, Hu W, Liu C, Zhang JG, Meng FG (2013) Brain stimulation for treatment of refractory epilepsy. Chinese Med J 126:3364-3370. Medline

Glickstein M (2007) What does the cerebellum really do? Curr Biol 17:R824-R827. CrossRef Medline

Godlevskii LS, Stepanenko KI, Lobasyuk BA, Sarakhan EV, Bobkova LM (2004) The effects of electrical stimulation of the paleocerebellar cortex on penicillin-induced convulsive activity in rats. Neurosci Behav Physiol 34:797-802. Medline

Gradinaru V, Zhang F, Ramakrishnan C, Mattis J, Prakash R, Diester I, Goshen I, Thompson KR, Deisseroth K (2010) Molecular and cellular approaches for diversifying and extending optogenetics. Cell 141:154-165. CrossRef Medline

Grimaldi G, Manto M (2012) Topography of cerebellar deficits in humans. Cerebellum 11:336-351. CrossRef Medline

Grimm RJ, Frazee JG, Bell CC, Kawasaki T, Dow RS (1970) Quantitative studies in cobalt model epilepsy: the effect of cerebellar stimulation. Int J Neurol 7:126-140. Medline

Hablitz JJ (1976) Intramuscular penicillin epilepsy in the cat: effects of chronic cerebellar stimulation. Exp Neurol 50:505-514. Medline

Hablitz JJ, McSherry JW, Kellaway P (1975) Cortical seizures following cerebellar stimulation in primates. Electroencephalogr Clin Neurophysiol 38:423-426. Medline

Hamani C, Andrade D, Hodaie M, Wennberg R, Lozano A (2009) Deep brain stimulation for the treatment of epilepsy. Int $J$ Neural Syst 19:213-226. CrossRef Medline

Haroian AJ, Massopust LC, Young PA (1981) Cerebellothalamic projections in the rat: an autoradiographic and degeneration study. J Comp Neurol 197:217-236. CrossRef Medline

Harper JW, Heath RG (1973) Anatomic connections of the fastigial nucleus to the rostral forebrain in the cat. Exp Neurol 39:285-292. Medline

Harvey AS, Jayakar P, Duchowny M, Resnick T, Prats A, Altman N, Renfroe JB (1996) Hemifacial seizures and cerebellar ganglioglioma: an epilepsy syndrome of infancy with seizures of cerebellar origin. Ann Neurol 40:91-98. CrossRef Medline

Haussler U, Bielefeld L, Froriep UP, Wolfart J, Haas CA (2012) Septotemporal position in the hippocampal formation determines epileptic and neurogenic activity in temporal lobe epilepsy. Cereb Cortex 22:26-36. CrossRef Medline

Heath RG, Harper JW (1974) Ascending projections of the cerebellar fastigial nucleus to the hippocampus, amygdala, and other tem- poral lobe sites: evoked potential and histological studies in monkeys and cats. Exp Neurol 45:268-287. Medline

Heath RG, Dempesy CW, Fontana CJ, Myers WA (1978) Cerebellar stimulation: effects on septal region, hippocampus, and amygdala of cats and rats. Biol Psychiatry 13:501-529. Medline

Heath RG, Dempesy CW, Fontana CJ, Fitzjarrell AT (1980) Feedback loop between cerebellum and septal-hippocampal sites: its role in emotion and epilepsy. Biol Psychiatry 15:541-556. Medline

Heck CN, King-Stephens D, Massey AD, Nair DR, Jobst BC, Barkley GL, Salanova V, Cole AJ, Smith MC, Gwinn RP, Skidmore C, Van Ness PC, Bergey GK, Park YD, Miller I, Geller E, Rutecki PA, Zimmerman R, Spencer DC, Goldman A, Edwards JC, Leiphart JW, Wharen RE, Fessler J, Fountain NB, Worrell GA, Gross RE, Eisenschenk S, Duckrow RB, Hirsch LJ, Bazil C, O'Donovan CA, Sun FT, Courtney TA, Seale CG, Morrell MJ (2014) Two-year seizure reduction in adults with medically intractable partial onset epilepsy treated with responsive neurostimulation: final results of the RNS System Pivotal trial. Epilepsia 55:432-441. CrossRef Medline

Hemmy DC, Larson SJ, Sances A, Jr., Millar EA (1977) The effect of cerebellar stimulation on focal seizure activity and spasticity in monkeys. J Neurosurg 46:648-653. CrossRef Medline

Hippenmeyer S, Vrieseling E, Sigrist M, Portmann T, Laengle C, Ladle DR, Arber S (2005) A developmental switch in the response of DRG neurons to ETS transcription factor signaling. PLoS Biol 3:e159. CrossRef Medline

Hutton JT, Frost JD Jr, Foster J (1972) the influence of the cerebellum in cat penicillin epilepsy. Epilepsia 13:401-408. Medline

Ivry RB, Baldo JV (1992) Is the cerebellum involved in learning and cognition? Curr Opin Neurobiol 2:212-216. Medline

Iwata K, Snider RS (1959) Cerebello-hippocampal influences on the electroencephalogram. Electroencephalogr Clin Neurophysiol 11: 439-446. Medline

Kahane P, Depaulis A (2010) Deep brain stimulation in epilepsy: what is next? Curr Opin Neurol 23:177-182. CrossRef Medline

Kandel A, Buzsaki G (1993) Cerebellar neuronal activity correlates with spike and wave EEG patterns in the rat. Epilepsy Res 16:1-9. Medline

Karceski S (2007) Electrical stimulation devices in the treatment of epilepsy. Acta Neurochir Suppl 97:247-259. Medline

Katoh YY, Benedek G (2003) Cerebellar fastigial neurons send bifurcating axons to both the left and right superior colliculus in cats. Brain Res 970:246-249. Medline

Klemm WR, Atkinson AV, Herron RE (1979) Evoked EEG responses in several motor areas of brain to stimulation of hippocampus and caudate, alone and in combination. Int J Neurosci 10:1-5. Medline

Kottamasu SR (1997) Brain imaging during seizure: ictal brain SPECT. Indian J Pediatr 64:575-580. Medline

Krauss GL, Koubeissi MZ (2007) Cerebellar and thalamic stimulation treatment for epilepsy. Acta Neurochir Suppl 97:347-356. Medline

Krook-Magnuson E, Armstrong C, Oijala M, Soltesz I (2013) Ondemand optogenetic control of spontaneous seizures in temporal lobe epilepsy. Nat Commun 4:1376. CrossRef Medline

Krook-Magnuson E, Ledri M, Soltesz I, Kokaia M (2014) How might novel technologies such as optogenetics lead to better treatments in epilepsy? Adv Exp Med Biol 813:319-336. CrossRef Medline

Laxpati NG, Kasoff WS, Gross RE (2014) Deep brain stimulation for the treatment of epilepsy: circuits, targets, and trials. Neurotherapeutics 11:508-526. CrossRef Medline

Lega BC, Halpern CH, Jaggi JL, Baltuch GH (2010) Deep brain stimulation in the treatment of refractory epilepsy: update on current data and future directions. Neurobiol Dis 38:354-360. CrossRef Medline

Levy LF, Auchterlonie WC (1979) Chronic cerebellar stimulation in the treatment of epilepsy. Epilepsia 20:235-245. Medline

Liu W, Zhang Y, Yuan W, Wang J, Li S (2012) A direct hippocampocerebellar projection in chicken. Anat Rec (Hoboken) 295:13111320. CrossRef Medline

Lockard JS, Ojemann GA, Congdon WC, DuCharme LL (1979) Cerebellar stimulation in alumina-gel monkey model: inverse relation- 
ship between clinical seizures and EEG interictal bursts. Epilepsia 20:223-234. Medline

Lockman J, Fisher RS (2009) Therapeutic brain stimulation for epilepsy. Neurol Clin 27:1031-1040. CrossRef Medline

Madisen L, Mao T, Koch H, Zhuo JM, Berenyi A, Fujisawa S, Hsu YW, Garcia AJ, 3rd, Gu X, Zanella S, Kidney J, Gu H, Mao Y, Hooks BM, Boyden ES, Buzsaki G, Ramirez JM, Jones AR, Svoboda K, Han X, Turner EE, Zeng H (2012) A toolbox of Credependent optogenetic transgenic mice for light-induced activation and silencing. Nat Neurosci 15:793-802. CrossRef Medline

Maiti A, Snider RS (1975) Cerebellar control of basal forebrain seizures: amygdala and hippocampus. Epilepsia 16:521-533. Medline

Mesiwala AH, Kuratani JD, Avellino AM, Roberts TS, Sotero MA, Ellenbogen RG (2002) Focal motor seizures with secondary generalization arising in the cerebellum: case report and review of the literature. J Neurosurg 97:190-196. CrossRef Medline

Miller JW (1992) The role of mesencephalic and thalamic arousal systems in experimental seizures. Prog Neurobiol 39:155-178. Medline

Morrell M (2006) Brain stimulation for epilepsy: can scheduled or responsive neurostimulation stop seizures? Curr Opin Neurol 19: 164-168. CrossRef Medline

Mutani R (1967) Cobalt experimental hippocampal epilepsy in the cat. Epilepsia 8:223-240. Medline

Mutani R, Bergamini L, Doriguzzi T (1969) Experimental evidence for the existence of an extrarhinencephalic control of the activity of the cobalt rhinencephalic epileptogenic focus. Part 2. Effects of the paleocerebellar stimulation. Epilepsia 10:351-362. Medline

Newman PP, Reza H (1979) Functional relationships between the hippocampus and the cerebellum: an electrophysiological study of the cat. J Physiol 287:405-426. Medline

Niedermeyer E, Uematsu S (1974) Electroencephalographic recordings from deep cerebellar structures in patients with uncontrolled epileptic seizures. Electroencephalogr Clin Neurophysiol 37:355365. Medline

Norden AD, Blumenfeld H (2002) The role of subcortical structures in human epilepsy. Epilepsy Behav 3:219-231. Medline

Osawa S, Iwasaki M, Hosaka R, Matsuzaka Y, Tomita H, Ishizuka T, Sugano E, Okumura E, Yawo H, Nakasato N, Tominaga T, Mushiake $\mathrm{H}$ (2013) Optogenetically induced seizure and the longitudinal hippocampal network dynamics. PloS One 8:e60928. CrossRef Medline

Paul SM, Heath RG, Ellison JP (1973) Histochemical demonstration of a direct pathway from the fastigial nucleus to the septal region. Exp Neurol 40:798-805. Medline

Paz JT, Davidson TJ, Frechette ES, Delord B, Parada I, Peng K, Deisseroth K, Huguenard JR (2013) Closed-loop optogenetic control of thalamus as a tool for interrupting seizures after cortical injury. Nat Neurosci 16:64-70. CrossRef Medline

Rahman M, Abd-El-Barr MM, Vedam-Mai V, Foote KD, Murad GJ, Okun MS, Roper SN (2010) Disrupting abnormal electrical activity with deep brain stimulation: is epilepsy the next frontier? Neurosurg Focus 29:E7. CrossRef Medline

Reimer GR, Grimm RJ, Dow RS (1967) Effects of cerebellar stimulation on cobalt-induced epilepsy in the cat. Electroencephalogr Clin Neurophysiol 23:456-462. Medline

Rochefort C, Arabo A, Andre M, Poucet B, Save E, Rondi-Reig L (2011) Cerebellum shapes hippocampal spatial code. Science 334:385-389. CrossRef Medline

Rochefort C, Lefort JM, Rondi-Reig L (2013) The cerebellum: a new key structure in the navigation system. Front Neural Circuits 7:35. CrossRef Medline

Saillet S, Langlois M, Feddersen B, Minotti L, Vercueil L, Chabardes S, David O, Depaulis A, Deransart C, Kahane P (2009) Manipulating the epileptic brain using stimulation: a review of experimental and clinical studies. Epileptic Disord 11:100-112.

Sinjab B, Martinian L, Sisodiya SM, Thom M (2013) Regional thalamic neuropathology in patients with hippocampal sclerosis and epi- lepsy: a postmortem study. Epilepsia 54:2125-2133. CrossRef Medline

Snider RS (1979) Focal cerebellar hyperthermia: effects on cerebral paroxysmal afterdischarges. Epilepsia 20:115-125. Medline

Snider RS, Maiti A (1975a) Cerebellar control of amygdaloid seizures. Transact Am Neurol Assoc 100:17-18. Medline

Snider RS, Maiti A (1975b) Septal afterdischarges and their modification by the cerebellum. Exp Neurol 49:529-539. Medline

Snider RS, Maiti A (1976) Cerebellar contributions to the Papez circuit. J Neurosci Res 2:133-146. CrossRef Medline

Soussi R, Boulland JL, Bassot E, Bras H, Coulon P, Chaudhry FA, Storm-Mathisen J, Ferhat L, Esclapez M (2014) Reorganization of supramammillary-hippocampal pathways in the rat pilocarpine model of temporal lobe epilepsy: evidence for axon terminal sprouting. Brain Struct Funct. Advance online publication. doi: 10.1007/s00429-014-0800-2.

Sprengers M, Vonck K, Carrette E, Marson AG, Boon P (2014) Deep brain and cortical stimulation for epilepsy. Cochrane Database Syst Rev 6:CD008497. CrossRef Medline

Sramka M, Fritz G, Galanda M, Nadvornik P (1976) Some observations in treatment stimulation of epilepsy. Acta Neurochir (Wien) [Suppl] 257-262.

Staba RJ, Ekstrom AD, Suthana NA, Burggren A, Fried I, Engel J, Jr., Bookheimer SY (2012) Gray matter loss correlates with mesial temporal lobe neuronal hyperexcitability inside the human seizureonset zone. Epilepsia 53:25-34. CrossRef Medline

Strain GM, Van Meter WG, Brockman WH (1978) Elevation of seizure thresholds: a comparison of cerebellar stimulation, phenobarbital, and diphenylhydantoin. Epilepsia 19:493-504. Medline

Strain GM, Babb TL, Soper HV, Perryman KM, Lieb JP, Crandall PH (1979) Effects of chronic cerebellar stimulation on chronic limbic seizures in monkeys. Epilepsia 20:651-664. Medline

Strick PL, Dum RP, Fiez JA (2009) Cerebellum and nonmotor function. Ann Rev Neurosci 32:413-434. CrossRef Medline

Sukhotinsky I, Chan AM, Ahmed OJ, Rao VR, Gradinaru V, Ramakrishnan C, Deisseroth K, Majewska AK, Cash SS (2013) Optogenetic delay of status epilepticus onset in an in vivo rodent epilepsy model. PloS One 8:e62013. CrossRef Medline

Theodore WH, Fisher RS (2004) Brain stimulation for epilepsy. Lancet Neurol 3:111-118. Medline

Tonnesen J, Sorensen AT, Deisseroth K, Lundberg C, Kokaia M (2009) Optogenetic control of epileptiform activity. Proc Nat Acad Sci U S A 106:12162-12167. CrossRef Medline

Tsai PT, Hull C, Chu Y, Greene-Colozzi E, Sadowski AR, Leech JM, Steinberg J, Crawley JN, Regehr WG, Sahin M (2012) Autistic-like behaviour and cerebellar dysfunction in Purkinje cell Tsc1 mutant mice. Nature 488:647-651. CrossRef Medline

Tykocki T, Mandat T, Kornakiewicz A, Koziara H, Nauman P (2012) Deep brain stimulation for refractory epilepsy. Arch Med Sci 8:805816. CrossRef Medline

Van Buren JM, Wood JH, Oakley J, Hambrecht F (1978) Preliminary evaluation of cerebellar stimulation by double-blind stimulation and biological criteria in the treatment of epilepsy. J Neurosurg 48:407-416. CrossRef Medline

Varga C, Golshani P, Soltesz I (2012) Frequency-invariant temporal ordering of interneuronal discharges during hippocampal oscillations in awake mice. Proc Natl Acad Sci U S A 109:E2726-2734. CrossRef Medline

Velasco F, Carrillo-Ruiz JD, Brito F, Velasco M, Velasco AL, Marquez I, Davis R (2005) Double-blind, randomized controlled pilot study of bilateral cerebellar stimulation for treatment of intractable motor seizures. Epilepsia 46:1071-1081. CrossRef Medline

Verveer C, Hawkins RK, Ruigrok TJ, De Zeeuw Cl (1997) Ultrastructural study of the GABAergic and cerebellar input to the nucleus reticularis tegmenti pontis. Brain Res 766:289-296. Medline

Wada JA (1974) Progressive seizure recruitment in subhuman primates and effect of cerebellar stimulation upon developed vs. developing amygdaloid seizures. Bol Estud Med Biol 28:285-301. Medline 
Wright GD, McLellan DL, Brice JG (1984) A double-blind trial of chronic cerebellar stimulation in twelve patients with severe epilepsy. J Neurol Neurosurg Psychiatry 47:769-774. Medline

Wyckhuys T, Geerts PJ, Raedt R, Vonck K, Wadman W, Boon P (2009) Deep brain stimulation for epilepsy: knowledge gained from experimental animal models. Acta Neurol Belg 109:63-80. Medline Wykes RC, Heeroma JH, Mantoan L, Zheng K, MacDonald DC, Deisseroth K, Hashemi KS, Walker MC, Schorge S, Kullmann DM (2012) Optogenetic and potassium channel gene therapy in a rodent model of focal neocortical epilepsy. Sci Transl Med 4:161ra152. CrossRef

Zhong XL, Yu JT, Zhang Q, Wang ND, Tan L (2011) Deep brain stimulation for epilepsy in clinical practice and in animal models. Brain Res Bull 85:81-88. CrossRef Medline

Zhu JN, Yung WH, Kwok-Chong Chow B, Chan YS, Wang JJ (2006) The cerebellar-hypothalamic circuits: potential pathways underlying cerebellar involvement in somatic-visceral integration. Brain Res Rev 52:93-106. CrossRef Medline 